\title{
SMART CITY SOLUTIONS IN SÖDRA MUNKSJÖN PROJECT IN JÖNKÖPING SWEDEN
}

\section{ROZWIAZANIA SMART CITY W PROJEKCIE STRATEGICZNYM SÖDRA MUNKSJÖN W JÖNKÖPING W SZWECJI}

\author{
Olga Gazińska \\ PhD Arch \\ Author's Orcid number: 0000-0003-1491-3073 \\ Zachodniopomorski Uniwersytet Technologiczny w Szczecinie \\ Wydział Architektury \\ Katedra Urbanistyki i Planowania Przestrzennego
}

\begin{abstract}
The paper presents analysis of Södra Munksjön project in terms of smart solutions. It was created for Swedish city Jönköping. Jönköping was highly placed in European Smart Cities rankings for medium-sized cities in EU. Both the project and development strategy of Jönköping commune do not mention smart solutions or smart city as a development strategy. Despite this, in the case of a project, sustainable solutions are identical to smart solutions.
\end{abstract}

Key words: smart city, sustainable development.

\section{STRESZCZENIE}

Artykuł przedstawia analizę projektu Södra Munksjön pod kątem rozwiązań wpisujących się w ideę smart city. Projekt jest realizowany w szwedzkim mieście Jönköping, które znalazło się na listach rankingowych European Smart Cities dla średniej wielkości miast UE, zajmując wysokie pozycje. Zarówno projekt jak i strategia rozwoju gminy nie odnoszą się bezpośrednio do smart city. Pomimo to w przypadku projektu rozwiązania zrównoważone są tożsame z rozwiązaniami smart.

Słowa kluczowe: smart city, miasto inteligentne, zrównoważony rozwój. 


\section{INTRODUCTION}

Jönköping is one of three Swedish cities included in the European Smart Cities rankings for medium-sized cities in the European Union. They were prepared consecutively in 2007, 2013 and 2014 by researchers of the Vienna University of Technology. The rankings considered EU cities with at least one university, urban population between 100,000. and 500,000 inhabitants ${ }^{1}$ and the catchment area of less than 1.500,000 inhabitants (Giffinger R., Gudrun H.). Jönköping was placed sixth in the latest ranking, after Umea and Eskilstuna, who came third and fourth (European Smart Cities 3.0 (2014), Ranking). Strategic and planning documents of Jönköping do not state smart city as development model nor do they mention smart city at all. Despite that sustainable solutions used in the city fit in with the smart city idea. The city itself is located at the southern end of Lake Vättern. Together with Husqvarna and Norrahammar-Houslatt, Jönköping behaves as one urban complex that co-decides in terms of development (fig.1 and fig.2). While in Poland city area is in case of most cities identical to commune area, Scandinavian cities are not separate communes. The administrative unit in Sweden is the commune (kommun) covering the area of the city and its surroundings, including smaller towns. Strategic and planning documents concern these entire areas, which results in a more systemic approach to development, not only for the city itself, but also for its neighbourhood. Strategic and planning documents are being made for whole area. It results in systemic approach to development for the main city and its commune. This way of development makes the application of sustainable development solutions easier - it helps prevents suburbanization and promotes compactness of the settlements. Scandinavian high level of prosperity and stability also contribute towards steady urban investments and development. Thanks to all elements above long-term, wide-ranging urban and architectural projects such as Södra Munksjön can be put through.

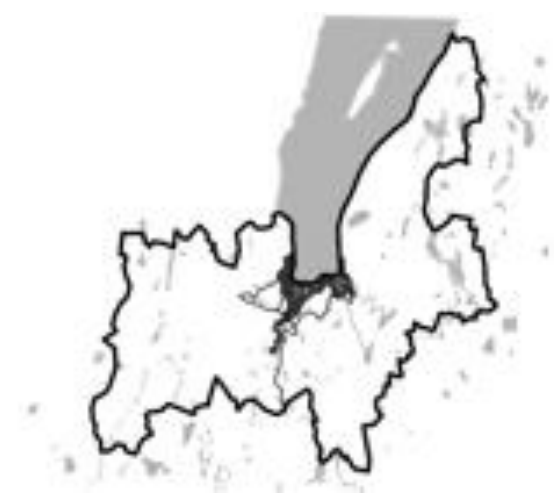

Fig. 1. Black border shows Jönköping Kommun; light grey - lakes and rivers; dark grey - Jönköping city with Husqvarna and Norrahammar-Houslatt. Source: author

Ryc. 1. Gmina Jönköping obramowana czarną obwódką, jasny szary - wody powierzchniowe; ciemny szary miasto Jönköping z Husqvarną i Norrahammar-Houslatt Źródło: autor

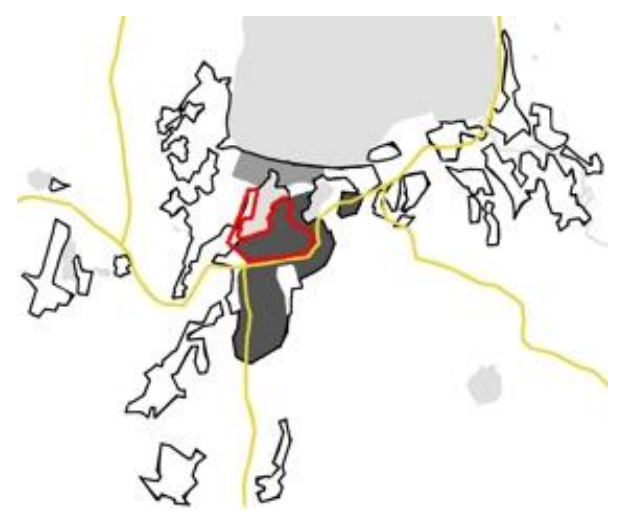

Fig. 2. Settlements of Jönköping city, Husqvarna (in the East) and Norrahammar-Houslatt (in the South); light grey lakes and rivers; medium grey - Jönköping city centre; dark grey - industrial areas; yellow lines - state roads; red border - Södra Munksjön project. Source: author

Ryc. 2. Zabudowa miasta Jönköping, Husqvarny (na wschodzie) i Norrahammar-Houslatt (na południu); jasny szary - wody powierzchniowe; średni szary - centrum miasta Jönköping; ciemny szary - tereny przemysłowe; żółte linie - drogi krajowe; czerwona ramka - projekt Södra Munksjön Źródło: autor

\footnotetext{
1 Jönköping Kommun has 139,2 thousand inhabitants, the city of Jönköping - 96,9 thousand. There are two universities in the city: Jönköping University and Jönköping International Business School.
} 


\section{METHODS}

The research area of the paper is the Södra Munksjön project in Jönköping (fig.3). It is a masterplan for the southern part of the city around Lake Munksjön. The project was selected as a case study for the analysis of sustainable solutions in terms of smart city idea. The author's first look at the project happened at the Jönköping Commune Office. Where the author spoke about the project idea with city representative. Afterwards the immediate vicinity of the yet to be launched project was visited and surveyed using observational methods. Particular attention was paid to the communication system, its connectivity and walkability, building functions and the urban greenery system. The next step was a thorough analysis of the collected materials related to the project. At this stage, the solutions presented in the project were compared with the categories of development according to the smart city idea.

Fig. 3. Södra Munksjön project. Source: Ramprogram 2012, p.11

Ryc. 3. Projekt Södra Munksjön. Źródło: Ramprogram 2012, s.11

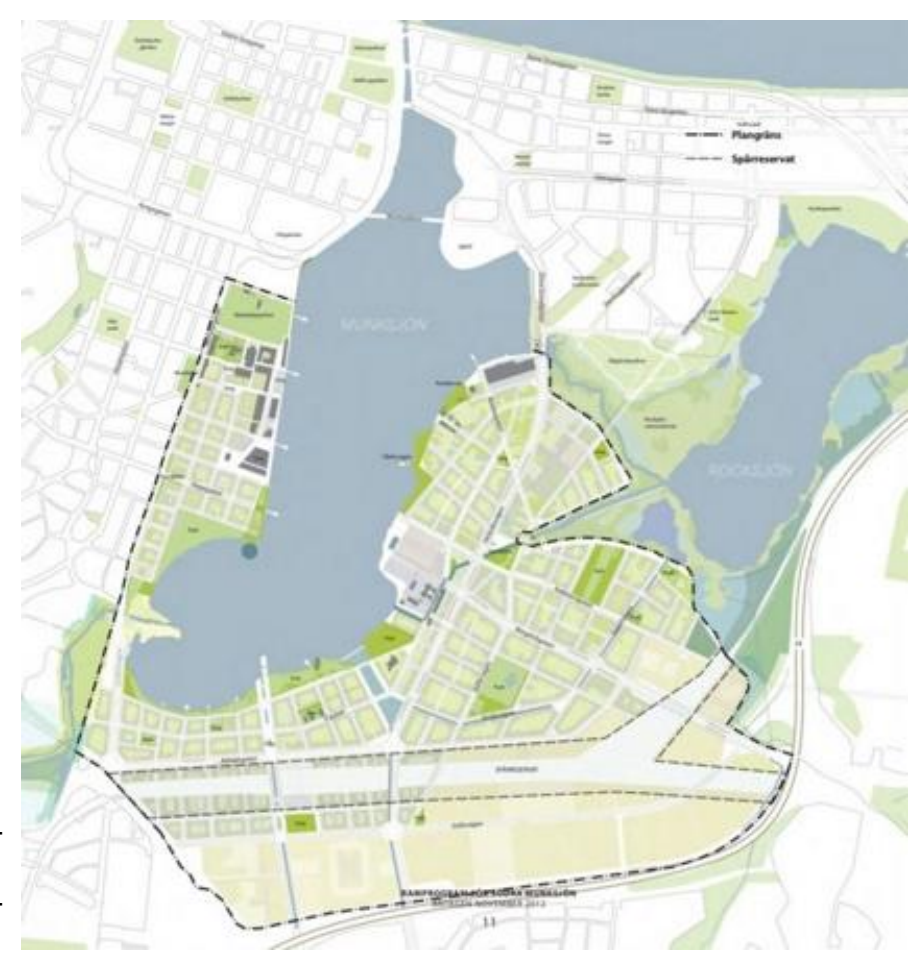

\section{SMART CITY AND SUSTAINABLE DEVELOPMENT IN JÖNKÖPING}

In November 2007, Jönköping signed Aalborg Commitments². Since then the city has been consistently developing according. In the document The Aalborg Commitments for Sustainable Cities \& Towns, the development vision for the city was proposed. It promotes development, creativity and sustainability for everyone, creating a good life. The good life is described as sustainable environment for all residents and the opportunity to participate in all aspects of urban life (The Aalborg Commitments for Sustainable Cities \& Towns, p.6). The city is developing sustainably according to the Aalborg Commitments. The current vision of the city's development also fits in with the sustainable development. The document Vision 2030 includes four main goals for Jönköping. They indi-

\footnotetext{
${ }^{2}$ Aalborg Commitments contain 10 main themes of development each splitting into five. The main goals are: governance (increase of the participation in decision making), local governance towards sustainable development (implementation of effective management cycles), environmental good (taking responsibility for environmental good), responsible consumption and lifestyle choices, planning and design, better mobility (less car traffic), local plan for public health, vibrant and sustainable local economy, social equality and justice, from local to global (global responsibility for peace, justice, equality, development and climate protection); (Aalborg Commitments)
} 
cate the place of the commune in the country and focus on innovation and human capital (Vision 2030 för Jönköping Kommun). Smart city presents holistic approach to development with the use of the latest technologies. Most definitions of smart city (Albino V., Berardi U., Dangelico R. M.), despite minor differences, repeat following key elements: the use of IT technologies (gathering and processing information in real time), human capital (creative, decision-making society), multidirectional sustainable development and high quality of life (Appio F., Lima M., Paroutis S.). Therefore, they fall into one of three categories: technological; social; sustainable. Emphasized element usually reflects the authors background (researchers, governments or IT companies) and intentions. Worth mentioning here is the nationwide Swedish Smart Cities platform. It brings together Swedish cities that develop with the use of smart and sustainable solutions (Smart City Sweden). The latest trends in development and urban projects are also shown on the platform. Jönköping however is not a part of this group of cities, even though the Södra Munksjön project fits both sustainable development and smart city.

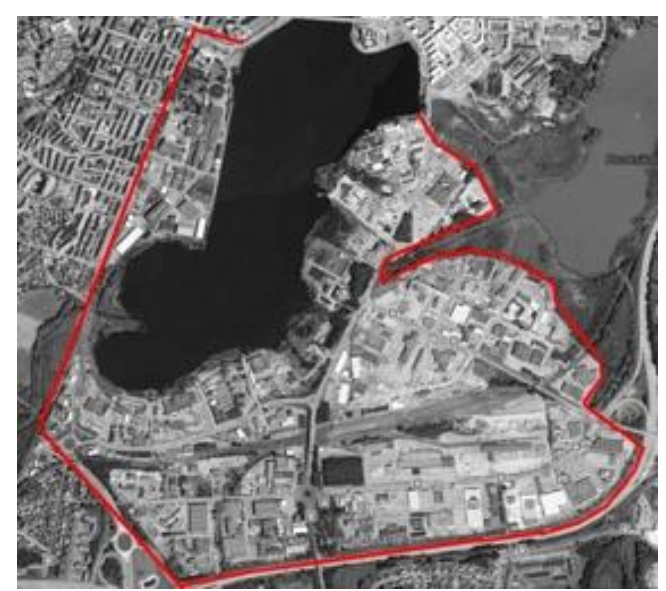

Fig. 4. Södra Munksjön area in 2010 before development of the project. Source: author

Ryc. 4. Obszar Södra Munsjon w 2010 roku przed opracowaniem projektu. Źródło: autor

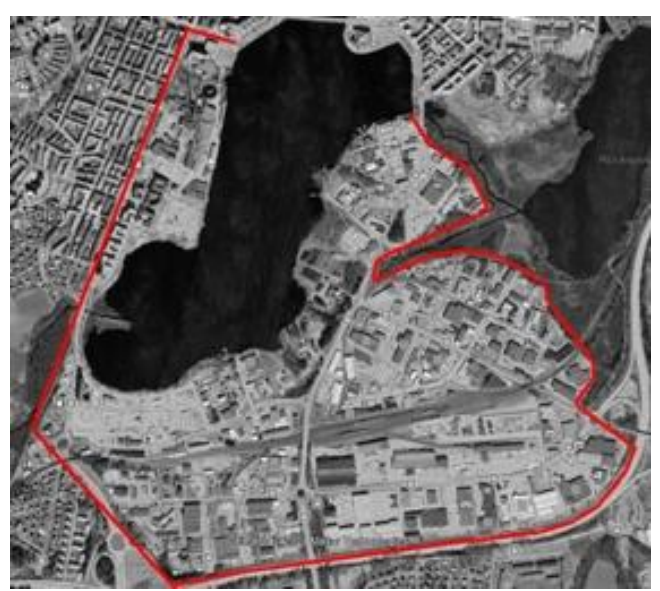

Fig. 5. Södra Munksjön project area in 2020 with visible changes in the urban tissue on the west and southwest side of the lake. Source: author

Ryc. 5. Obszar projektu Södra Munsjon w 2020 roku z widocznymi zmianami $w$ tkance miejskiej na zachodnim i południowo-zachodnim brzegu jeziora. Źródło: autor

\section{THE SÖDRA MUNKSJÖN PROJECT}

The Södra Munksjön project was created for the southern part of the city. Currently it serves as the industrial area (fig.4). According to the project a complete change of urban tissue is planned, along with a new communication system. The plan covers an area of 296 hectares, including a part of Lake Munksjön. The buildings are to be multi-functional organised into city blocks. The project has estimated population of 12,000-14,000 inhabitants. The northern part in predominantly residential. While southern part, by the railway and the new station, is composed of mostly non-residential functions such as office, retail and entertainment, with approximately 11,500 workplaces and $453,000 \mathrm{~m}^{2}$ of retail space. The project was created based on the sustainable development. Its solutions take into account following aspects: culture, urban landscape, greenery and natural environment, water environment, recreation, communication and accessibility, protection against noise pollution, clean air, risk of contamination of the area, risk of landslides, entrepreneurs, climate change and resource management (Miljökonsekvensbeskrivning..., p. 3). The Södra Munksjön project is the city's flagship project. At first it was to be completed in 2030. In the result of the project Jönköping should become a more attractive and competitive city. The Munksjön project in- 
volves the creation of a new, multi-functional district closely related to the existing city. Currently, the western part of the project has been completed (fig.5).

The analysis of the Södra Munksjön project in terms of smart city solutions was carried out based on the smart city model presented by European Smart Cities. Among the six directions of smart city development, the project can be considered in three of them: mobility, quality of life, environment.

\subsection{Mobility}

The smart mobility category consists of four domains: local accessibility, (inter-)national accessibility, availability of IT-infrastructure, sustainability of the transport system (Giffinger R., Fertner C., Kramar H., Meijers E.). Local accessibility and a sustainable transport system play the greatest role in the urban structure. (Inter) -national accessibility extends beyond spatial planning at the municipal level. However, in the Södra Munksjön project it was considered thanks to the railway station project, which is expected to be an important transport hub in southern Sweden. Solutions providing access to IT infrastructure are not visible in the city and do not affect the appearance of the public space. Local availability depends on the quality of public transport. The three components that make up local accessibility, according to European Smart Cities, are: public transport network per inhabitant, access to public transport, quality of public transport (Giffinger R., Fertner C., Kramar H., Meijers E.). The Munksjön project was designed to facilitate walking, cycling and public transport. Accessibility and connectivity were the most important factors in creating road system. The project also revitalizes railway area. Existing railway station is to be rebuild together with the immediate soundings (Södra Munksjön...). Public transport is to be vastly extended, especially with the launch of the urban high-speed railway and the creation of a tram network. Moreover, the expansion of the bus network is planned (including the purchase of biogas buses). Additionally, the creation of a water tram on Lake Munksjön is planned (Ramprogram..., s. 30-37).

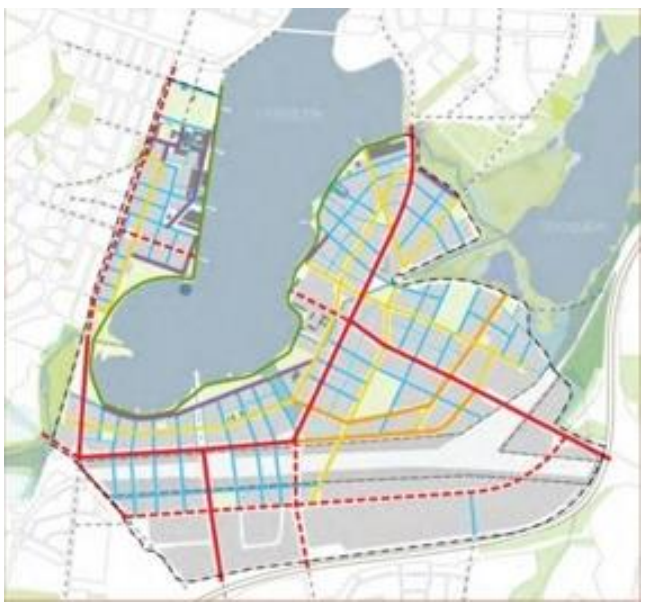

Fig. 6. Street system in Södra Munksjön project with different street width and functions. Source: Ramprogram 2012, p.34

Ryc. 6. System drogowy w projekcie Södra Munksjön z różnym zagospodarowaniem ulic. Źródło: Ramprogram 2012, p.34

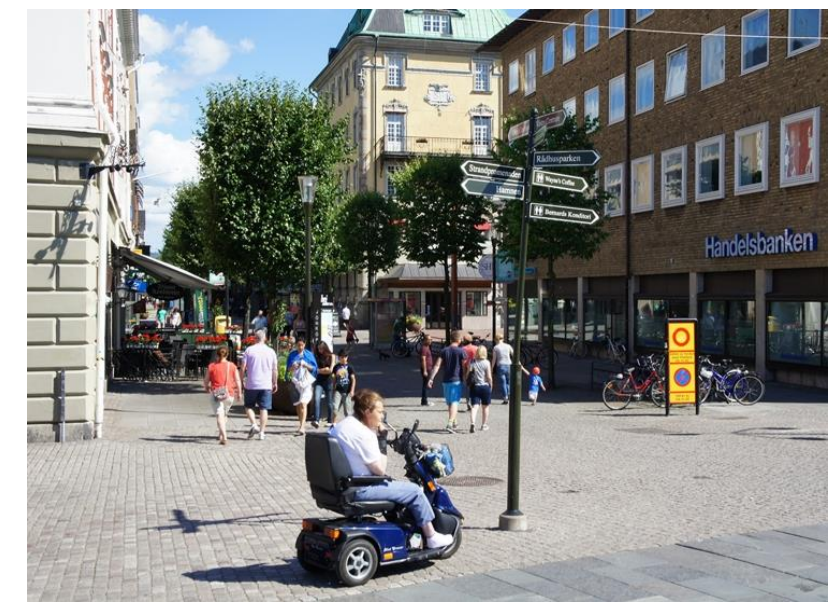

Fig. 7. Example of shared space street in Jönköping, Östra Storgatan. Source: author (2015)

Ryc. 7. Przykład pieszojezdni w Jönköping, Östra Storgatan. Źródło: autor (2015)

\subsection{Quality of life}

The quality of life category (smart living) is directly related to the functions planned in the area, mainly health care, education and culture institutions. This category includes seven domains: cultural facilities, health conditions, individual security, housing quality, education facilities, and touristic attractiveness. economic welfare (Giffinger R., Fertner C., Kramar H., Meijers E.). Cultural facili- 
ties is the first domain, it is measured by statistical data on the activity of inhabitants related to attendance. These components are: cinema attendance, museums visits, theatre attendance. They are not directly related to the architectural form and solutions used in the buildings. Although, the more amenities used, design in universal manner, the greater the potential group of recipients. The Södra Munksjön project was designed to create a multifunctional, diversified space (fig. 8). The buildings are to be of high quality and have a varied architectural forms. The city blocks of the project are directly connected with the existing urban tissue, maintaining the continuity of the urban fabric. The project creates three local centres in which city life is to focus. In the immediate vicinity of these centres and the streets adjoining them, the ground floors of buildings are to be used as commercial spaces (fig.9). Differentiation of functions occurs not only within the entire project or its section, but also within each city block (Ramprogram..., p. 38-45). The project also creates educational institutions: schools (3), kindergartens (9), as well as places for spending free time and learning for the elderly. Cultural facilities are also design throughout the project. The $19^{\text {th }}$ century industrial architecture is to be preserved as the important heritage. Those buildings are to be transformed for new functions(Ramprogram..., s. 12-23, 38-45).

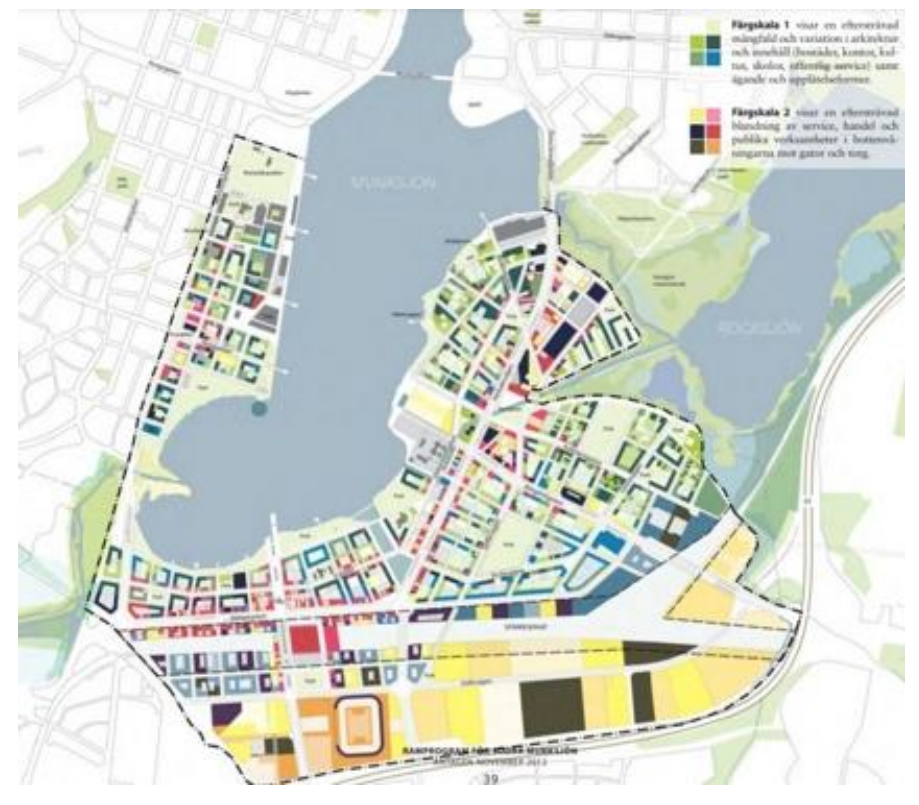

Fig. 8. Södra Munksjön project, functions division: Colour scale 1 shows diversity and variation in architecture and functions (housing, offices, culture, schools, public services) as well as ownership and forms of lease; Colour scale 2 shows a mix of service, trade and public activities on the ground floors towards streets and squares. Source: Ramprogram 2012, p.39

Ryc. 8. Projekt Södra Munksjön, podział na funkcje: Skala kolorów 1 pokazuje zróżnicowanie architektury i funkcji (mieszkania, biura, kultura, szkoły, usługi publiczne), a także prawa własności i formy najmu; Skala kolorów 2 przedstawia połączenie usług, handlu i działalności publicznej w parterach w kierunku ulic i placów. Żródło: Ramprogram 2012, s.39

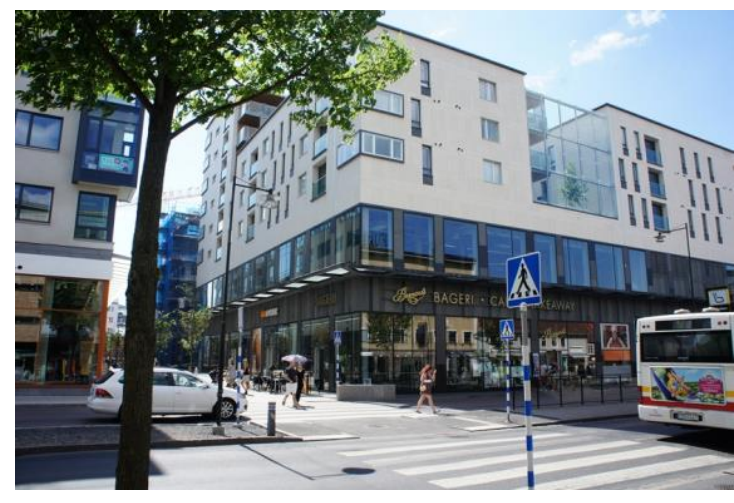

Fig. 9. New development on the north side of Munksjön Lake, Södra Strandgatan. Source: author (2015)

Ryc. 9. Nowa zabudowa na północnej części jeziora Munksjön, Södra Strandgatan. Źródło: autor (2015)

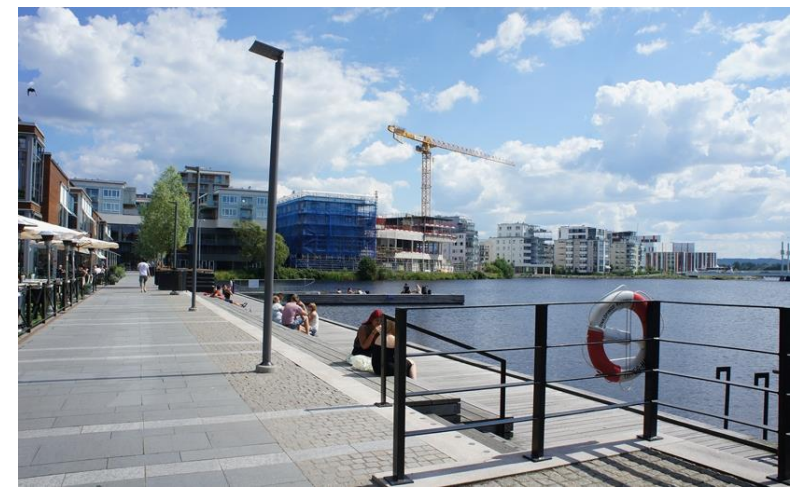

Fig. 10. New development on the north waterfront of Munksjön Lake. Source: author (2015)

Ryc. 10. Nowa zabudowa na północnym nabrzeżu jeziora Munksjön. Źródło: autor (2015) 


\subsection{Environment}

The domains of the smart environment category are: environmental conditions, air quality (no pollution), ecological awareness, and sustainable resource management (Giffinger R., Fertner C., Kramar H., Meijers E.). One of the components of strictly urban environmental conditions is the share of green spaces (Giffinger R., Fertner C., Kramar H., Meijers E.). Designing green spaces with the city is important from both an environmental and a social point of view. High-quality green spaces can be obtained by networking them with green corridors. Planning city greenery this way ensures ecological continuity, which at the same time increases the availability of green areas for residents. Planning greenery in a systemic way influences other aspects of city life, including: reduction of air pollution, reduction of noise pollution, increase of humidity, and additional retention areas (Rawski K. L.), it also has a positive effect on the human health and psyche (Gallacher J., Sarkar C., Webster C.; Eling J., Hands A., Petrokofsky C., and others). The Södra Munksjön project increases the percentage of green areas (fig.11 and fig.12). It also protects and expands the existing connections of green areas and creating new ones. As part of the project, the greenery at the neighbouring Lake Rocksjön (fig.14) and other existing green sparces are to be preserved. Among the buildings, many park areas of four different types are proposed: park squares, ornamental parks, activity parks and green parks. Connections between green areas are to be strengthened by designing street greenery on most streets. Streets with the width of $35 \mathrm{~m}, 25 \mathrm{~m}$ and $18 \mathrm{~m}$ are designed with at least two tree belts, $15 \mathrm{~m}$ wide streets with one tree belt. There are more green solution introduced such as: city air purifiers (fig.13), green facades and roof (Ramprogram..., s. 24-29).

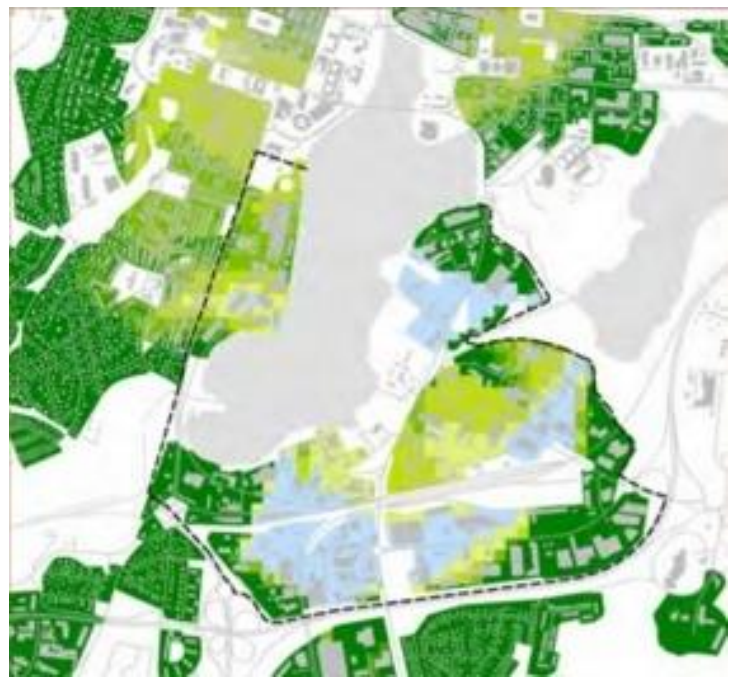

Fig. 11. Current green areas $\left(\mathrm{m}^{2}\right)$ per person, in gradation from the darkest green - $10 \mathrm{~m}^{2} /$ person, to blue - less than $2 \mathrm{~m}^{2} /$ person. Source: Ramprogram 2012, p.26

Ryc. 11. Obecne powierzchnia obszarów zielonych $\left(\mathrm{m}^{2}\right)$ na osobę, w gradacji od najciemniejszego zielonego - 10 $\mathrm{m}^{2}$ /osobę, do niebieskiego - poniżej $2 \mathrm{~m}^{2}$ osobę. Źródło: Ramprogram 2012, s.26

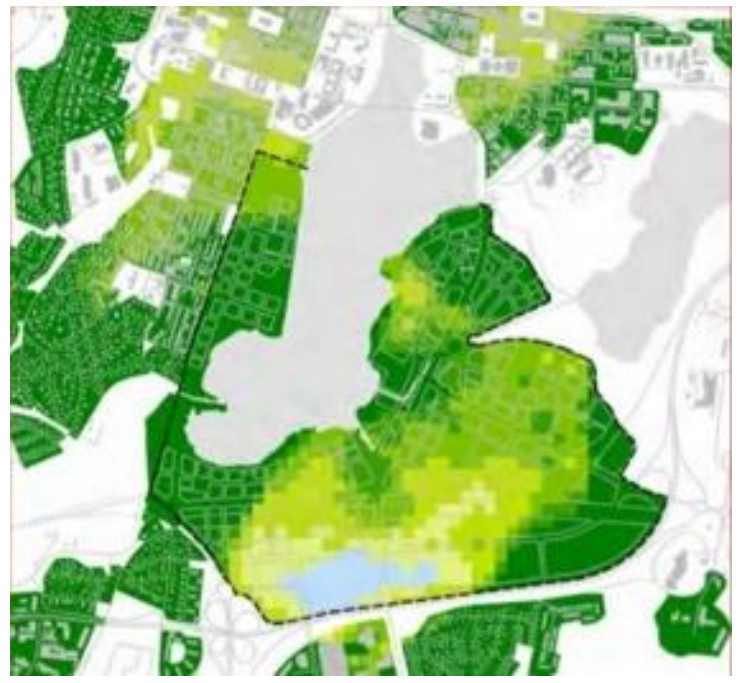

Fig. 12. Future green areas $\left(\mathrm{m}^{2}\right)$ per person, in gradation from the darkest green - $10 \mathrm{~m}^{2} /$ person, to blue - less than $2 \mathrm{~m}^{2} /$ person. Source: Ramprogram 2012, p.26

Ryc. 12. Projektowana powierzchnia obszarów zielonych $\left(\mathrm{m}^{2}\right)$ na osobę, w gradacji od najciemniejszego zielonego $10 \mathrm{~m}^{2} /$ osobę, do niebieskiego - poniżej $2 \mathrm{~m}^{2} /$ osobę. Żródło: Ramprogram 2012, p.26

\section{CONCLUSION}

Mobility, quality of life and environmental solutions link the smart city with sustainable development. Analysing the definitions of the smart city and the solutions presented in the Södra Munksjön project, it can be concluded that the smart city model largely coincides with the sustainable development. Sustainable development is the development that meets the needs of the present without compromising the ability of future generations to meet their own needs (Organizacja Narodów Zjednoczonych...). Sustainable development is planned on three levels: economic, social and environmental. The goals of sustainable development, defined by the United Nations, coincide with the 
categories defined by the smart city and going beyond them. While a characteristic feature of a smart city is the extensive use of the latest ICT solutions, the main goal of sustainable development according to UN is combating poverty. If only for this reason, sustainable development is a more basic model of development that focuses on the human being, his equality with other people and his well-being in the most essential matters. The analysed project is an example of a holistic approach to city development shown by Scandinavian cities. The Södra Munksjön project has been consulted with the inhabitants many times. It is multifunctional, focused on people and social interactions. It is not a single project, but is related to other investments carried out in the area of the entire commune, being the result of a coherent spatial policy. Concurrently with the introduction of modern solutions using ICT technology, Jönköping implements a policy of sustainable development. The Södra Munksjön is long-term project and it involves many investors, both private and public. Moreover, a holistic, systemic approach to urban space is visible. The solutions adopted in the project, especially regarding road infrastructure, affect the entire city, changing the way people move around it. This way of approach to development is very close to the smart city idea, as it responds to many challenges, additionally using technological solutions.

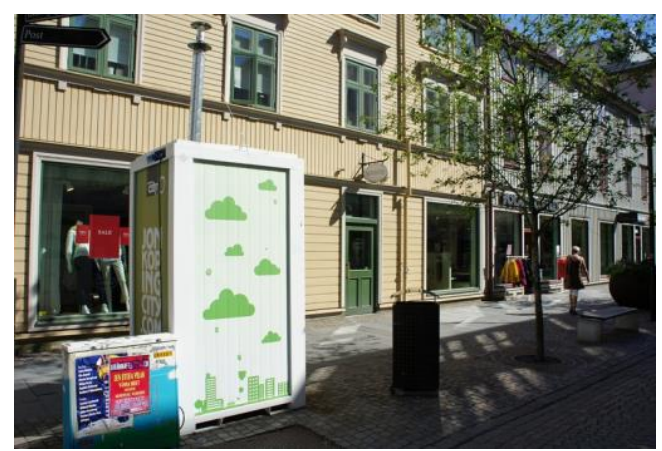

Fig. 13. Air pollution monitoring and treatment facility in Jönköping Centre. Source: author (2015)

Ryc. 13. Obiekt monitorujący zanieczyszczenie powietrza i oczyszczający je w centrum Jönköping. Źródło: autor (2015)

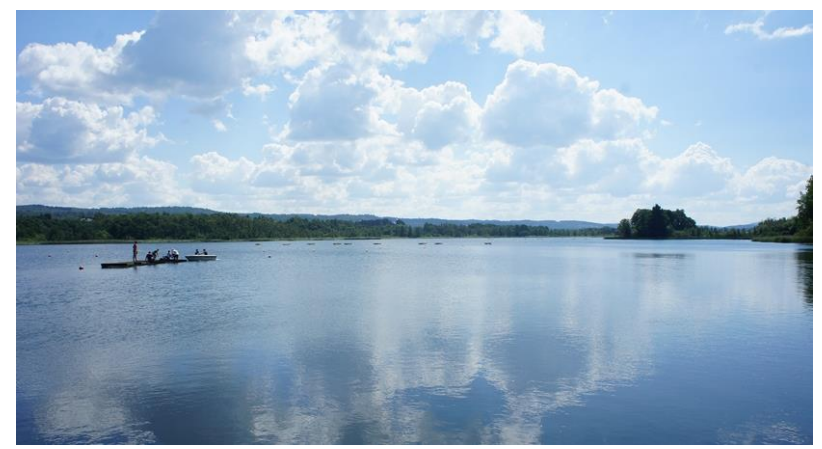

Fig. 14. Natural greenery of Lake Rocksjon. Source: author (2015)

Ryc. 14. Naturalna zieleń jeziora Rocksjon. Źródło: autor (2015)

\section{ROZWIAZANIA SMART CITY W PROJEKCIE STRATEGICZNYM SÖDRA MUNKSJÖN W JÖNKÖPING, W SZWECJI}

\section{WSTĘP}

Jönköping jest jednym z trzech szwedzkich miast, które znalazły się w rankingach European Smart Cities dla średnich miast Unii Europejskiej, przeprowadzonych w latach 2007, 2013 i 2014 przez Uniwersytet Technologiczny w Wiedniu. W rankingu wzięte zostały pod uwagę miasta Unii Europejskiej mające przynajmniej jeden uniwersytet, liczebność między 100 tys. a 500 tys. mieszkańców $^{3}$ oraz zasięg oddziaływania mniejszy niż 1.500 tys. mieszkańców (Giffinger R., Gudrun $\mathrm{H}_{\text {.). }}$. W ostatnim z rankingów Jönköping zajęło szóstą pozycję, przed Umeą i Eskilstuną, które zajęły trzecie i czwarte miejsce (European Smart Cities 3.0 (2014), Ranking). Pomimo że w dokumentach planistycznych i strategicznych Jönköping nie ma formalnego zapisu o smart city jako modelu rozwoju, rozwiązania stosowane w mieście wpisują się w ideą smart city. Miasto położone jest na

\footnotetext{
${ }^{3}$ Liczba ludności w Jonkoping Kommun wynosi 139,2 tys., w samym mieście natomiast 96,9 tys. Miasto posiada dwa uniwersytety: Uniwersytet Jonkoping i Jonkoping International Business School.
} 
południowym krańcu jeziora Wetter. Razem z Husquarną i Norrahammar-Houslatt tworzy spójny organizm miejski (ryc.1 i ryc.2), współdecydujący w zakresie rozwoju. Z uwagi na zupełnie inny od polskiego podział administracyjny, miasta skandynawskie nie są odrębnymi gminami. Jednostką administracyjną w Szwecji są gminy (kommun) obejmujące obszar miasta i jego najbliższych okolic, w tym także mniejszych miejscowości. Dokumenty strategiczne i planistyczne dotyczą całych tych obszarów, co skutkuje bardziej systemowym podejściem do rozwoju, nie tylko samego miasta, ale i jego sąsiedztwa. Planowanie rozwoju dla tak określonego terenu ułatwia także stosowanie rozwiązań zrównoważonego rozwoju - przeciwdziała suburbanizacji i sprzyja kompaktowości. Elementem sprzyjającym przyjmowanym rozwiązaniom przestrzennym jest także wysoki poziom dobrobytu miast skandynawskich i ich stabilność. Dzięki temu długoterminowe, szeroko zakrojone projekty urbanistyczno-architektoniczne takie jak Södra Munksjön są realizowane.

\section{METODY}

Obszarem badań jest teren projektu Södra Munksjön w Jönköping (ryc.3). Jest to masterplan obejmujący południową część miasta wokół jeziora Munksjön. Projekt został wybrany jako studium przypadku do analizy przyjętych rozwiązań zrównoważonych pod kątem idei smart city. Pierwsze zapoznanie się autorki z projektem i jego ideą nastąpiło w Urzędzie Gminy Jönköping. Następnie najbliższe sąsiedztwo jeszcze nie rozpoczętego projektu, północne nabrzeże jeziora Munksjön, został zbadane na miejscu metodą obserwacyjną. Zwrócono szczególną uwagę na system komunikacji i łatwość w poruszaniu się, funkcje zabudowy, system zieleni miejskiej. Kolejnym krokiem było dokładna analiza zgromadzonych materiałów dotyczących projektu. Na tym etapie zestawiono przyjęte w projekcie rozwiązania z kategoriami rozwoju według idei smart city.

\section{SMART CITY I ROZWÓJ ZRÓWNOWAŻONY W JÖNKÖPING}

W listopadzie 2007 roku miasto podpisało Aalborg Commitments4 i od tego czasu konsekwentnie rozwija się w myśl idei zrównoważonego rozwoju. W dokumencie The Aalborg Commitments for Sustainable Cities \& Towns, wizja, którą ma podążać miasto, opisana jest jako promująca rozwój, kreatywność i zrównoważone miasta dla każdego; kreująca dobre życie - zrównoważone środowisko dla wszystkich mieszkańców i możliwość uczestniczenia we wszystkich aspektach życia miejskiego (The Aalborg Commitments for Sustainable Cities \& Towns, s.6). Zgodnie z zapisami zobowiązań z Aalborg miasto postępuje w idei zrównoważonego rozwoju. Aktualna wizja rozwoju miasta wpisuje się $\mathrm{w}$ ideę zrównoważonego rozwoju. W dokumencie Vision 2030 zostały zapisane cztery najważniejsze cele dla Jönköping, wskazują one miejsce gminy w kraju, innowacyjność i kapitał ludzki (Vision 2030 för Jönköpings Kommun). Smart city jako idea rozwoju miast opiera się na holistycznym podejściu do rozwoju z wykorzystaniem najnowszych technologii. W większości definicji smart city (Albino V., Berardi U., Dangelico R. M.) pomimo różnic powtarzają kilka kluczowych elementów: wykorzystanie nowoczesnych technologii (zbieranie i przetwarzanie informacji w czasie rzeczywistym), kapitał ludzki (kreatywne, decyzyjne społeczeństwo), wielokierunkowy zrównoważony rozwój i wysoką jakość życia (Appio F., Lima M., Paroutis S.). Można zatem przydzielić definicje do trzech kategorii: technologicznej, społecznej i zrównoważonej. Podkreślane elementy definicji zazwyczaj związane są z autorem (badaczami, rządami lub władzami miast i firmami IT) i intencjami stworzenia definicji. Wartą wspomnienia jest ogólnokrajowa szwedzka platforma Smart Cities. Zrzesza ona szwedzkie miasta rozwijające się z wykorzystaniem rozwiązań inteligentnych i zrównoważonych (Smart City Sweden). Jönköping jednakże nie należy do tej grupy miast, pomimo że projekt Södra Munksjön wpisuje się zarówno w ideę zrównoważonego rozwoju, jak i smart city.

\footnotetext{
${ }^{4}$ Zobowiązania z Aalborg dzielą się na 10 celów głównych, z których każdy składa się z pięciu celów pośrednich. Główne cele to: zarzadzanie (zwiększenie udziału demokracji partycypacyjnej w podejmowaniu decyzji), lokalne zarządzanie w kierunku zrównoważonego rozwoju (wdrażanie efektywnych cykli zarządzania), naturalne dobra wspólne (wzięcie odpowiedzialności za dobra naturalne), odpowiedzialna konsumpcja i wybory stylu życia, planowanie i projektowanie, lepsza mobilność (mniejszy ruch samochodowy), lokalne działania na rzecz zdrowia, tętniąca życiem i zrównoważona lokalna gospodarka, równość społeczna i sprawiedliwość, z lokalnego w globalny (zakładanie globalnej odpowiedzialności za pokój, sprawiedliwość, równość, rozwój i ochronę klimatu); (Aalborg Commitements).
} 


\section{PROJEKT SÖDRA MUNKSJÖN}

Projekt Södra Munksjön został stworzony dla południowej części miasta, gdzie obecnie znajdują się tereny przemysłowe (ryc.4). Planowana jest całkowita zmiana zabudowy, razem z nowym układem komunikacyjnym. Plan obejmuje powierzchnię 296 hektarów, w tym także część jeziora Munksjön. Zabudowa ma być głównie w układzie kwartałowym o wielofunkcyjnym charakterze. $\mathrm{Na}$ obszarze projektu na docelowo zamieszkać 12.000-14.000 mieszkańców. Północna część projektu ma przeważającą funkcję mieszkalną. Natomiast w południowej części przy torach kolejowych i nowym dworcu przeważać mają następujące funkcje: biurowa, handlowa i rozrywkowa. Na obszarze ma znaleźć się około 11.500 miejsc pracy i $453000 \mathrm{~m}^{2}$ powierzchni handlowych. Projekt został stworzony w oparciu o ideę zrównoważonego rozwoju, i ma zawierać rozwiązania uwzględniające: kulturę, pejzaż miejski, zieleń i środowisko naturalne, środowisko wodne, rekreację, komunikację i dostępność, ochronę przed zanieczyszczeniem hałasem, czyste powietrze, ryzyko skażenia terenu, ryzyko osuwisk, przedsiębiorców, oraz zmianę klimatu i zarządzanie zasobami (Miljökonsekvensbeskrivning..., s.3). To ambitne przedsięwzięcie jest flagowym projektem miasta. Na początku zakończenie projektu planowano na rok 2030. W rezultacie projektu Jönköping ma stać się miastem bardziej atrakcyjnym i konkurencyjnym. Projekt Munksjön zakłada stworzenie nowej, wielofunkcyjnej dzielnicy ściśle powiązanej z miastem. Obecnie zrealizowana została zachodnia część projektu znajdująca się najbliżej istniejącej zabudowy (ryc.5). Analiza projektu Munksjön pod kątem rozwiązań smart city przeprowadzona została bazując na modelu smart city przedstawionym przez European Smart Cities. Wśród sześciu kierunków rozwoju smart city projekt można rozpatrywać w trzech: mobilność, jakość życia, ochrona środowiska.

\subsection{Mobilność}

W kategorii mobilność (smart mobility) znalazły się cztery domeny: dostępność lokalna, dostępność (między)-narodowa, dostęp do infrastruktury IT, zrównoważony system transportowy (Giffinger R., Fertner C., Kramar H., Meijers E.). Dostępność lokalna i zrównoważony system transportowy odgrywają największą rolę w strukturze urbanistycznej miasta. Dostępność (między)-narodowa wykracza poza planowanie przestrzenne na poziomie gminy, natomiast w projekcie Munksjön została uwzględniona dzięki projektowi stacji kolejowej, która ma stanowić ważny węzeł komunikacyjny w południowej Szwecji. Rozwiązania zapewniające dostęp do infrastruktury IT nie są widoczne w mieście i nie wpływają na wygląd przestrzeni. Dostępność lokalna zależna jest od jakości transportu zbiorowego. Trzema komponentami składającymi się na dostępność lokalną, według European Smart Cities, są: sieć transportu publicznego na jednego mieszkańca, dostęp do transportu publicznego, jakość transportu publicznego (Giffinger R., Fertner C., Kramar H., Meijers E.). Projekt Munksjön został skonstruowany tak, żeby ułatwić poruszanie się pieszo, na rowerze i transportem publicznym. Dostępność i łączność z istniejącą tkanką miejską były najważniejszymi czynnikami wpływającymi na wygląd systemu drogowego. Projekt zakłada także rewitalizację terenów kolejowych. Istniejąca stacja kolejowa ma być przebudowana razem z jej najbliższym otoczeniem (Södra Munksjön...). Projekt rozbudowuje także system komunikacji miejskiej, szczególnie przez uruchomienie szybkiej kolei miejskiej i utworzenie sieci tramwajowej. Ponadto planowane jest zwiększenie sieci autobusowej (w tym zakupienie autobusów na biogaz). Dodatkowym elementem w systemie komunikacji miejskiej ma być stworzenie wodnego tramwaju na jeziorze Munksjön (Ramprogram..., s. 30-37).

\subsection{Jakość życia}

Kategoria jakość życia (smart living) jest bezpośrednio związana z planowanymi na obszarze funkcjami, głównie są to placówki ochrony zdrowia, edukacji i kultury. W tej kategorii znalazło się siedem domen: obiekty kultury, warunki zdrowotne, bezpieczeństwo indywidualne, jakość zabudowy mieszkaniowej, obiekty edukacji, atrakcyjność turystyczna, dobrobyt gospodarczy (Giffinger R., Fertner C., Kramar H., Meijers E.). Obiekty kultury są pierwszą z domen, mierzoną za pomocą danych statystycznych dotyczących aktywności mieszkańców związanych z konkretnymi obiektami kultury. Komponenty te dotyczą: publiczności kinowej, wizyt muzealnych, publiczności teatralnej. Nie są one bezpośrednio związane z rozwiązaniami architektonicznymi obiektów, natomiast im więcej zastosowanych udogodnień, związanych z projektowaniem uniwersalnym, tym większa jest potencjalna rzesza odbiorców danych obiektów. W projekcie Munksjön zadbano o stworzenie wie- 
lofunkcjonalnej zróżnicowanej przestrzeni (ryc.8). Budynki mają cechować się wysoką jakością i zróżnicowanym wyrazem architektonicznym. Zabudowa $w$ projekcie bezpośrednio łączy się $\mathrm{z}$ istniejącą zabudową, zachowując ciągłość tkanki miejskiej. Projekt zakłada powstanie trzech lokalnych centrów, w których ma skupiać się życie miejskie. W najbliższych okolicach tych centrów i ulicach do nich dochodzących partery zabudowy mają być usługowe (ryc.9). Zróżnicowanie funkcji pojawia się nie tylko w ramach całego projektu lub jego sekcji, ale także w ramach każdego kwartału zabudowy (Ramprogram..., s. 38-45). W obszarze mają powstać placówki edukacji: szkoły (3), przedszkola (9), a także miejsca spędzania wolnego czasu i nauki dla osób starszych. Zaprojektowano także wiele obiektów kultury. Industrialna XIX-wieczna zabudowa ma zostać w większości zachowana jako świadectwo historii. Obiekty te mają zostać dostosowane do nowych funkcji (Ramprogram..., s. 12-23, 38-45).

\section{3. Środowisko}

Domenami kategorii środowisko (smart environment) są: warunki środowiskowe, jakość powietrza (brak zanieczyszczenia), świadomość ekologiczna, zrównoważone zarządzanie zasobami (Giffinger R., Fertner C., Kramar H., Meijers E.). Jednym z komponentów warunków środowiskowych, ściśle urbanistycznych, jest udział przestrzeni zielonych (Giffinger R., Fertner C., Kramar H., Meijers E.). Projektowanie przestrzeni zielonych z mieście jest istotne $z$ punktu widzenia środowiskowego, ale przede wszystkim społecznego. Zielone przestrzenie wysokiej jakości można zyskać przez połączenie ich w sieć z użyciem zielonych korytarzy. Takie planowanie zieleni zapewnia ciągłość ekologiczną, co równocześnie zwiększa dostępność terenów zielonych dla mieszkańców. Myślenie o zieleni w sposób systemowy ma wpływ na inne aspekty życia w mieście, m.in. zieleń zmniejsza ilość zanieczyszczeń powietrza, niweluje hałas, podnosi wilgotność, będąc dodatkowo terenami retencyjnymi (Rawski K. L.) wreszcie wpływa pozytywnie na zdrowie i psychikę ludzką (Gallacher J., Sarkar C., Webster C.; Eling J., Hands A., Petrokofsky C., i in.). Projekt zakłada zwiększenie udziału procentowy zieleni, razem z zachowaniem istniejących powiązań terenów zielonych i tworzeniem nowych (ryc. 13 i ryc.14). W ramach projektu zachowano zieleń przy sąsiednim jeziorze Rocksjon (ryc.12), a także inną zieleń istniejącą. Wśród projektowanej zabudowy zaproponowano wiele terenów parkowych w czterech różnych typach: place parkowe, parki ozdobne, parki aktywności i parki zielone. Wzmocniono połączenia między terenami zielonymi poprzez zaprojektowanie zieleni przyulicznej na większości ulic. Ulice o szerokościach $35 \mathrm{~m}, 25 \mathrm{~m}$ i $18 \mathrm{~m}$ zaprojektowano z co najmniej dwoma pasami zieleni wysokiej, ulice o szerokości $15 \mathrm{~m} \mathrm{z}$ jednym pasem zieleni wysokiej. W projekcie zaproponowano więcej rozwiązań ekologicznych takich jak: miejski oczyszczacz powietrza (ryc.11), zielone fasady i dachy (Ramprogram..., s. 24-29).

\section{WNIOSKI}

Rozwiązania dotyczące komunikacji, jakości życia i środowiska wiążą model smart city ze zrównoważonym rozwojem. Analizując przykłady definicji smart city oraz rozwiązania przedstawione w projekcie Södra Munksjön można stwierdzić, że model smart city pokrywa się w dużym stopniu z ideą zrównoważonego rozwoju. Zrównoważony rozwój ma na celu zaspokajanie potrzeb obecnego pokolenia w taki sposób, aby nie uniemożliwić zaspokojenia swoich potrzeb przyszłym pokoleniom (Organizacja Narodów Zjednoczonych...). Zrównoważony rozwój planowany jest na trzech płaszczyznach: ekonomicznej, społecznej i środowiskowej. Cele zrównoważonego rozwoju, określone przez ONZ, pokrywają się z kategoriami wyznaczonymi przez model smart city, wykraczając również poza nie. O ile charakterystyczną cechą smart city jest szerokie wykorzystanie najnowszych rozwiązań ICT, o tyle główną cechą zrównoważonego rozwoju jest walka z ubóstwem. Chociażby z tego powodu zrównoważony rozwój jest bardziej podstawowym modelem rozwoju, który w najistotniejszych kwestiach skupia się na człowieku, jego równości wobec innych ludzi oraz na jego dobrobycie. Przeanalizowany projekt jest przykładem holistycznego podejścia do rozwoju miasta, który wykazują miasta skandynawskie. Projekt Munksjön został wielokrotnie konsultowany z mieszkańcami, jest wielofunkcyjny, nastawiony na człowieka i interakcje społeczne. Nie jest to projekt jednostkowy, tylko wiąże się z innymi inwestycjami realizowanymi na terenie całej gminy, będąc efektem spójnej polityki przestrzennej. Równolegle z wprowadzaniem nowoczesnych rozwiązań wykorzystującymi technologię ICT, Jönköping realizuje politykę zrównoważonego rozwoju. Projekt Munksjön jest długoterminowy i angażujące wielu inwestorów, zarówno prywatnych, jak 
i publicznych. Ponadto widoczne jest holistyczne, systemowe podejście do przestrzeni miejskiej. Rozwiązania, szczególnie dotyczące infrastruktury drogowej, przyjęte w projekcie oddziałują na całe miasto, zmieniając sposób poruszania się po nim. Takie podejście do rozwoju wpisuje się w ideę smart city, gdyż odpowiada na wiele wyzwań, dodatkowo wykorzystując rozwiązania technologiczne.

\section{BIBLIOGRAPHY}

Aalborg Commitments: https://sustainablecities.eu/the-aalborg-commitments/ access/ dostęp 2021.02.24 Albino V., Berardi U., Dangelico R. M., Smart Cities: Definitions, Dimensions, Performance, and Initiatives, Journal of Urban Technology, 22(1):2015

Appio F., Lima M., Paroutis S., Understarnding Smart Cities: Innovation Ecosystems, Technological Advancements, and Societal Challenges, https://www.researchgate.net/publication/ 329092950_Understanding_Smart_Cities_Innovation_Ecosystems_Technological_Advancements_and_ Societal_Challenges, access/dostęp: 2021.02.17

Eling J., Hands A., Petrokofsky C., Ridgley H., Stimpson A.; Public Health, Health Inequality and Access to Green Space: A Scoping Review; Public Health England

European Smart Cities 3.0 (2014), Ranking: http://www.smart-cities.eu/?cid=3\&ver=3 , access/ dostęp 2021.02.24

European Smart Cities 3.0, The smart city model: http://smart-cities.eu/?cid=2\&ver=3 , access/ dostęp 2021.02.24

Gallacher J., Sarkar C., Webster C., Residential greenness and prevalence of major depressive disorders: a cross-sectional, observational, associational study of 94879 adult UK Biobank participants; Lancet Planet Health 2018, p.162-173

Giffinger R., Fertner C., Kramar H., Meijers E., City-ranking of European Medium-Sized Cities: http://www.smart-cities.eu/download/city_ranking_final.pdf, , access/ dostęp 2021.02.17

Giffinger R., Gudrun H., Smart cities ranking: An effective instrument for the positioning of the cities: https://www.researchgate.net/publication/228915976_Smart_cities_ranking_An_effective_instrument_for the_positioning_of_the_cities, access/ dostęp 2021.02.17

Jönköping Kommun, Befolkningsstatistik,: https://www.jonkoping.se/kommunpolitik/ kommunfakta/statistikochutredningar/befolkningsstatistik.4.74fef9ab15548f0b80090f.html, , access/ dostęp 2021.02.10

Miljökonsekvensbeskrivning, Ramprogram för södra Munksjön - fördjupad översiktsplan Inom Stadsbyggnadsvision 2.0, Jönköping Kommun, March 2012

Organizacja Narodów Zjednoczonych, Zrównoważony rozwój i Cele Zrównoważonego Rozwoju: http://www.unic.un.org.pl/strony-2011-2015/zrownowazony-rozwoj-i-cele-zrownowazonegorozwoju/2860, access/ dostęp 2021.02.24

Ramprogram för södra Munksjön, antagen av Kommunfullmak tige 29 November 2012: https://www.jonkoping.se/download/18.74fef9ab15548f0b8001b423/1465889738113/Ramprogram+Mun ksjon+Jkpg.pdf, access/ dostęp 2021.02.10

Rawski K. L., Greenery Planning for Improvement of Urban Air Quality - A Review; Proceedings 2019

Smart City Sweden: https://smartcitysweden.com/, access/ dostęp 2021.02.24

Södra Munksjön, Station Area: https://sodramunksjon.se/download/18.56ac98861555437 aa2624281/1472217040197/Next\%20J\%C3\%B6nk\%C3\%B6ping\%20WEB.pdf, access/ dostęp 2021.02.10

The Aalborg Commitments for Sustainable Cities \& Towns. Baseline Review - Jönköping Municipality september 2008, Jönköping Kommun

Vision 2030 för Jönköpings Kommun: https://www.Jönköping.se/kommunpolitik/ vision2030.4.3b0dbe715c33ff661c5f3b9.html, access/ dostęp 2021.02.10

\section{AUTHOR'S NOTE}

In her research, the author is interested in contemporary visions of urban development, including smart city, mainly in the social aspect.

\section{O AUTORZE}

Autorka w pracy naukowej interesuje się współczesnymi wizjami rozwoju miast, w tym smart city, głównie w aspekcie społecznym. 